Article

\title{
Efficiency Evaluation of Regional Sustainable Innovation in China: A Slack-Based Measure (SBM) Model with Undesirable Outputs
}

\author{
Kai Xu ${ }^{1}$, Bart Bossink ${ }^{2, *}$ and Qiang Chen ${ }^{1}$ \\ 1 School of Economics and Management, Tongji University, Shanghai 200092, China; \\ njuxk1988@163.com (K.X.); chenqiang@tongji.edu.cn (Q.C.) \\ 2 Faculty of Science, Division of Science, Business \& Innovation, Vrije Universiteit Amsterdam, \\ 1081 HV Amsterdam, The Netherlands \\ * Correspondence: b.a.g.bossink@vu.nl
}

Received: 19 November 2019; Accepted: 16 December 2019; Published: 18 December 2019

\begin{abstract}
An efficiency evaluation of China's regional sustainable innovation, evaluating industrial waste and total energy consumption, is the main research subject in this paper. It focuses on a regional measurement and comparison of these undesirable outputs of Chinese firm activities, such as industrial $\mathrm{SO}_{2}$ and $\mathrm{CO}_{2}$ emissions. By applying a data envelopment analysis-slack-based measure (DEA-SBM) model with undesirable outputs indicators, the regional innovation efficiency was evaluated for 30 provinces in China, from 2002 to 2014. The results indicate that the sustainable innovation efficiency of overall China is still relatively low, and varies significantly in different regions. Central and Western China have similar sustainable innovation efficiencies, which are much lower than the sustainable innovation efficiency in Eastern China. Furthermore, the data indicate that regional sustainable innovation efficiency disparities among these three areas are decreasing. Based on these findings, reasons for the sustainable innovation efficiency gap among the different regions were analyzed. To scholars, this paper extends the research on regional sustainable innovation efficiency by implementing an undesirable output perspective to the DEA-SBM model. The findings also provide Chinese policy makers with useful decision support insights for regional sustainable innovation, and energy conservation and emission reduction policies.
\end{abstract}

Keywords: regional sustainable innovation efficiency; undesirable outputs; slack-based measure model; regional disparities

\section{Introduction}

A country's technological innovation activities always have obvious regional characteristics [1-4], and the efficiency of regional innovation can differ among regions [5-8]. Technological innovation can be seen as a main driver of regional development and economic growth [9], but at the same time can also bring sincere damage to the natural environment when it is unsustainable [10]. The evaluation of sustainable innovation efficiency, especially in China, with its large population of 1395 million inhabitants, and large industrial activity, counting up to a yearly gross domestic product (GDP) of 90,030.9 trillion Yuan (which equals 13.605 trillion dollars) in 2018 [11], is an important topic. Insights coming from such evaluations can help to define policy and institutional actions to improve China's environmentally sustainable innovation and production. Such evaluations, especially on a regional level, are of great importance and are appropriate, since disparities in innovation performance between Chinese regions are reported to be increasing [12]. Starting from the concept of the national innovation system [13], Cooke [14] proposed a regional innovation system approach in which regional innovation 
differences can be addressed [15-17]. Research on regional innovation efficiency has gained increasing attention in recent years [18-20], but to the best of our knowledge, very few studies have been conducted to quantitatively evaluate sustainable innovation efficiency in China, by means of focusing on undesirable outputs like industrial $\mathrm{SO}_{2}$ and $\mathrm{CO}_{2}$ emissions [21,22]. Our study aims to contribute to the knowledge in this area, and does this by means of measuring and comparing unsustainable, unwanted, and undesirable outcomes/byproducts of Chinese regions' innovative firm activities. By evaluating the regional sustainable innovation efficiency of 30 provinces in China from 2002 to 2014, using the slack-based measure (SBM) model, this study focuses on the following research question: what are the differences between sustainable innovation efficiencies of different regions in China and which trends in these differences can be estimated?

How to deal with $\mathrm{SO}_{2}$ and $\mathrm{CO}_{2}$ emissions and with related climate change has become one of the most urgent challenges of today's world. For example, it has been reported that global $\mathrm{CO}_{2}$ emissions from fuel combustion has increased from 26,177 Mt in 2004 to 32,190 Mt in 2013 [23]. Many countries have committed to controlling $\mathrm{SO}_{2}$ and $\mathrm{CO}_{2}$ emissions and aim to develop a no- to low-emissions economy. In 2015, the Paris Climate Change Conference adopted the "Paris Agreement" to deal with climate change after 2020 [24]. More than 170 countries jointly signed the Paris Agreement in 2016. China and the United States officially ratified the Paris Agreement in 2016, and while the United States declared its withdrawal in 2017 [25], China may play a more important role in coping with global climate change. It is reported that by the year 2013 China had issued 358 laws and regulations on environmental protection, and 67 Chinese standards and requirements were enacted by March 2016 [26]. The Chinese government has become increasingly aware of the urgency of implementing environmental regulations and policies.

This study takes the mentioned unsustainable outputs like $\mathrm{SO}_{2}$ and $\mathrm{CO}_{2}$ emissions, henceforth called "undesirable outputs", into consideration by applying a data envelopment analysis-slack-based measure (DEA-SBM) model with new data, which can better reflect China's regional sustainable innovation efficiency than previous research $[9,19,27]$. The contribution of this paper to science and scholars is that it extends quantitative research methodology and findings on regional sustainable innovation efficiency, by applying the DEA-SBM model, and by integrating undesirable output into the comparison and evaluation. This research compares the efficiency of eastern, central, and western China regions, and analyzes the regional sustainable innovation efficiency on the macro level. To policy and practice, this evaluation can provide useful decision support insights for regional sustainable innovation, energy conservation, and emission reduction policies.

This paper is structured in six sections, of which this Section 1 is introductory. The Section 2 reviews relevant literature on regional innovation systems and sustainable innovation efficiency measurement in these regional innovation systems, and raises five hypotheses as the basis for the empirical study in this paper. Section 3 describes the DEA-SBM research methodology, and selection of methods and indicators in detail. In Section 4, the DEA-SBM model with undesirable outputs is adopted to evaluate the sustainable innovation efficiency of China's 30 provinces. Results and comparative analysis of innovation efficiency of eastern, central, and western China are displayed. Section 5 discusses the research outcomes and provides insights into the scholarly implications of the research, the limitations of the research approach that is chosen, and concludes with avenues for further research. Finally, main conclusions are drawn and policy implications are pointed out in the sixth section.

\section{Regional Sustainable Innovation Efficiency Evaluation}

\subsection{Regional Sustainable Innovation}

The national innovation system (NIS) is generally considered to be a nation-wide network structure composed of governments, scientific research institutions, financial institutions, enterprises and intermediaries, and as an organic whole that promotes the entire country to achieve innovative 
goals like sustainable development [13]. All components of the national network structure are more or less dependent upon the degree to which they participate in the network and are open for counterparts connected with, and affected by the flow of knowledge and new technological opportunities that circulate in the network. Many researchers have paid considerable attention to research on structure, characteristics, and mechanisms of the national innovation system [13,28-32]. According to Cooke $[14,17,33]$, the regional innovation system (RIS) is a local network structure, often situated in the larger structure of a national innovation system, also consisting of governmental bodies, research institutions, financial institutions, enterprises, and intermediaries, in which these entities are divided as well as associated with each other, generating and supporting innovation on a regional level. Regional cooperation in an RIS designed to promote innovation between organizations can be divided into several dimensions, involving highly specialized public research institutions, public universities, private companies, and government intervention [34]. Enterprises are the main body of technological innovation and the core of the regional innovation system. The central and local government aims to create a good environment for innovation activities, and regulates and guides innovation activities. Universities and research institutions promote the generation and dissemination of knowledge by participating in scientific research and technology development activities, and financial institutions provide funding sources and financial advice to reduce research and development (R\&D) risks. A nation is often composed of several regions [35]. Regions often differ in culture, politics, economy, and innovative environment [33,36-38]. Agglomerations of organizations in a business sector in a region tend to enhance knowledge creation and knowledge flow in and between these organizations, which promotes knowledge flow and innovation system development [39]. Regional innovation systems are significant components of a national innovation system, greatly affecting the quality and efficiency of the national innovation system [40]. The innovation system is usually defined as a set of organizations and the causal relationships that influence the generation, utilization, and performance of innovations in and between these organizations [41]. The concept of RIS has been widely used to illustrate the successful development of many innovative regions in developed and developing economies [42]. Establishing or strengthening an RIS has become a key policy goal for governments, with the aim of making their corporations and industries more globally competitive through various actions at the regional level [43]. By using the RIS infrastructure, firms interact with the RIS to enhance their absorptive capacity and innovation performance [44]. An RIS pays more attention to the geographic scope of the innovation processes than an NIS [45]. An RIS is an effective carrier of technological innovation on a regional level, and regional differences have led to different development trajectories. By focusing on RISs and enabling countries to take specific sustainable development measures in different regions, the solution to sustainable development issues can be fine-tuned to the specific circumstances of a region [46-48]. Due to the large national innovation system of China [31], with significant inequalities in economic and technology development among Chinese regions [49-53], it is appropriate to study China's innovation position by means of a focus on regional innovation systems, and by studying these systems to develop an insight into differences between regions $[54,55]$. The effectiveness of $R \& D$ investment depends on the interaction between local producers and knowledge users [56]. Industry agglomerations affect the innovation outputs of China's RISs, indicating that the benefits of a local economy depend on the development of regional institutions [57]. Regional innovation performances vary greatly due to China's regional differences in R\&D capabilities, government support, composition, and industrial environment [58]. This leads to Hypothesis 1 (see Table 1). 
Table 1. Hypotheses.

\begin{tabular}{lr}
\hline$\#$ & Hypothesis \\
\hline 1 & Sustainable innovation efficiencies differ to a considerable degree among Chinese regions. \\
2 & Sustainable innovation efficiency scores are much lower when undesirable outputs are taken into account. \\
3 & Sustainable innovation efficiency in China has risen in recent years. \\
4 & Sustainable innovation efficiency is higher in eastern than in central and western China. \\
5 & Sustainable innovation efficiency shows increasing regional disparities in China. \\
\hline
\end{tabular}

Based on the core concepts of innovation, energy conservation, and environmental protection, sustainable innovation combines sustainable development with innovation. In recent decades, researchers have devoted in-depth studies into connotation, index systems, ability appraisal, and theory models of sustainable innovation and the relationship between innovation and sustainability [59-61]. Technological innovation is critical to sustainable development, since it can improve resource utilization efficiency, reduce pollutant emissions, and overcome environmental constraints [46,62]. Regional technological innovation can be an important force for regional sustainable development, and improving the level of regional technological innovation can be an effective way to improve regional sustainable development capabilities [63]. While innovation studies often refer to new product development, process and service innovation, and economic growth by means of these activities [64], sustainable innovation expands this approach to social, institutional, ethical, and ecological dimensions [65]. Sustainable innovation research often stresses the minimization or complete absence of harmful environmental effects of the innovation process and/or this innovation process's outcomes, including, for example, the reduction of environmental waste and greenhouse gas emissions [27,66-68]. Effective methods to achieve sustainable development also include controlling population growth and economic development, while strengthening technological innovation to reduce the impact on the environment. Goals of sustainable innovation can be to improve sustainable innovation efficiency by means of, for example, alleviating excessive dependence on virgin natural materials, destruction of landscape, and use of fossil-based forms of energy [21,69-71]. Given the growing worldwide attention on environmentally sustainable innovation, it has become increasingly important to consider how to balance innovation in new product development, process and service innovation, and economic growth with environmentally sustainable innovation goals, like pollution mitigation and energy conservation [72]. Nowadays, with more and more concerns about industrial waste and global warming, decreasing undesirable outputs like greenhouse gas emissions and waste generation have to be taken into account in innovation efficiency evaluations in China [21,73,74]. Jinpeng Fu [75], for example, measured the dynamic regional efficiency of China using undesirable outputs, including unemployment, waste water, and waste, and Li et al. [76] comprehensively evaluated the regional sustainable development of the Yangzte River Economic Belt in China, based on undesirable output indicators like pollution, disasters, and accidents. In this line of research, Chen et al. [77] assessed the regional sustainability of the Beijing-Tianjin-Hebei urban agglomeration in China, and found an improved economic sustainability, but also a reduced environmental sustainability. Furthermore, Shen et al. [78] and Chen et al. [79] found that strategies and measures have brought spatial imbalances in the development of most cities in China, which have severely hampered regional sustainable development. This leads to Hypothesis 2 (see Table 1).

Economic development relies on energy consumption and the environment [80,81]. In the past 40 years, China has experienced a high economic growth [82-85], at the expense of natural resources and environmental quality [86-88]. In 2007, China became the largest contributor to $\mathrm{CO}_{2}$ emissions in the world [89]. When looking at this more specifically, it can be argued that China's economic growth led to industrial pollution and $\mathrm{CO}_{2}$ emissions that negatively impacted China's sustainable growth. Since China's further economic development remains a main important policy choice, the country also urgently needs a sustainable innovation component in its policy to neutralize undesirable outputs of economic innovation trajectories, and to contribute to an upgrade of the sustainable 
innovation efficiency of Chinese regions [90,91]. As the world's largest developing country and largest energy consumer and carbon emitter, China needs to put great effort into coping with global climate change. China's central government has stressed the importance of energy saving and greenhouse gas emission reduction policies, and showed an increasing determination to move on to seek sustainable development as well as to contribute to climate change goals that have been set internationally [92]. In recent years, the Chinese government has implemented policies on environmental regulations and energy consumption, and has achieved significant results. For example, in 2015, China planned to reduce $\mathrm{CO}_{2}$ emissions per unit of GDP by 17\% from the 2010 levels [93]. Chinese government declared to address global climate change and major pollutants in the 13th Five-Year Plan. In order to control carbon emissions and achieve emission reduction commitment, China established a nationally-unified carbon emissions trading market and improved related laws and regulations. This leads to Hypothesis 3 (see Table 1).

\subsection{Regional Sustainable Innovation Efficiency Evaluation}

The innovation process can be framed as the whole process of new product and service development, from the conception of an idea, to the development of a new product and/or service, to successful commercial market launch and sales. Innovation efficiency reflects the transformation performance of input into the innovation process, compared to the output of this innovation process [94]. Previous research found a strong correlation between innovation input and output, i.e., the higher the investment input, the higher the output that will be generated by the innovation process [94-98]. This does not mean that increasing the investment input will directly lead to an increased output, but that an increasing input often shows that output also increases. A regional sustainable innovation process can be framed as an innovation input-output process.

Researchers, both from China and other nations, have evaluated regional innovation efficiency at length, and the main studies are summarized here. Zabala-Iturriagagoitia et al. [99] evaluated the innovation efficiency in European countries and analyzed the relationship between technological level and system coordination. Li [12] applied this approach in China and found increasing disparities in overall innovation efficiency between Chinese regions through a stochastic frontier model. Chen and Guan [19] measured the efficiency of China's regional innovation system through a two-stage network DEA model and found that one-fifth of China's provinces could be classified as best-practice province, leaving the other four-fifths of provinces at the other side of the line. Han, Asmild, and Kunc [6] evaluated the R\&D efficiency patterns of 15 Korean regions and classified the regions into deteriorating, lagging, and improving groups. Carayannis et al. [100] integrated an assessment and classification framework for national and regional innovation efficiency based on a set of 23 European countries and their 185 corresponding regions, and discovered large innovation efficiency differences. Wang et al. [9] explored the environmental components of regional innovation efficiency in China, including economic infrastructure, the quality and structure of innovators, and regional openness, and found a chain structure relationship between regional innovation environmental components and innovation efficiency. Broekel, Rogge, and Brenner [7] proposed a robust shared-input DEA model to compute regions' innovation efficiency, and found a considerable variance in regional innovation efficiencies among German regions. Li et al. [5] observed a considerable regional variation in innovation efficiency in China through DEA estimates, and found a positive effect of foreign direct investment on regional innovation efficiency. Chen et al. [27] measured the regional R\&D and commercialization efficiencies for the high-tech industries in China through a network DEA method, and found that most of the Chinese regions had a low efficiency, while eastern China had a higher innovation efficiency than central and western China. Chen et al. [101] developed a dynamic analytical framework of regional R\&D efficiency systems, considering the dynamic interdependence between regional $R \& D$ activities over different periods, and they ascertained that eastern China had a higher efficiency than other provinces. 
To date, the relationship between sustainable innovation and innovation efficiency has been vague [70]. Several researchers have paid attention to the performance and efficiency of sustainable innovation. Shin et al. [70] calculated the innovation efficiency of Korean companies, considering sustainability through a DEA method, and found that environmental improvement could negatively affect innovation efficiency. Wang et al. [21] studied the innovation efficiency of green performance in 29 sectors of China's manufacturing industry, and found a shift to green innovation in these sectors. They also found a great innovation disparity between eastern and western China, and that the gap tended to increase across regions. Based on the above previous research, Hypothesis 4 and Hypothesis 5 are raised (see Table 1).

\section{Methodology and Methods}

There are already many studies on innovation efficiency, yet studies that focus on sustainable innovation efficiency, integrating undesirable outputs into the analysis, are still scarce. We focused on an evaluation and analysis of China's regions' sustainable innovation efficiency, integrating the undesirable outputs, mainly industrial waste and total energy consumption, into our methodology and methods.

\subsection{Data Envelopment Analysis}

Efficiency evaluation methods mainly include parametric and nonparametric evaluation methods. As a representative of the collection of nonparametric methods, the data envelopment analysis (DEA) method can deal with multi-output analysis, and is a frequently used method in efficiency research on energy, environment, ecology, and technological innovation [102-104]. Within a set of comparable decision-making units (DMUs), DEA provides an ordinal ranking of relative efficiency, and identifies the best practices leading to the identification of an efficient frontier, which means more output cannot be obtained by increasing input. The DEA method was first introduced by Charnes et al. [105], to measure the relative efficiency and productivity of DMUs by comparing multiple inputs and multiple outputs. The first DEA model, the CCR (Charnes, Cooper, and Rhodes) model, assumes that there are $n$ DMUs, and each DMU has $m$ inputs and $s$ outputs. The input-oriented CCR model is expressed as follows:

$$
\begin{aligned}
& \min \theta \\
& \text { s.t. } \sum_{j=1}^{n} \lambda_{j} x_{j} \leq \theta x_{0} \\
& \quad \sum_{j=1}^{n} \lambda_{j} y_{j} \geq y_{0} \\
& \quad \sum \lambda_{j}=1 ; \lambda_{j} \geq 0, j=1,2, \ldots, n
\end{aligned}
$$

where $\theta$ denotes the efficiency of the DMU. When $\theta=1$, the DMU is called DEA efficient. Banker et al. [106] expanded the assumption under constant return to scale, and proposed the DEA model under the condition of variable return to scale which was called BCC (Banker, Charnes\& Cooper) model.

\subsection{DEA-SBM Model}

All traditional DEA models are either input-oriented or output-oriented, without considering input and output slacks. In order to overcome the shortcomings of these existing models, Tone [107] proposed a non-radial and non-angle slack-based measure model, which solves the slack problems of inputs and outputs by directly putting the slack variables into the objective function. After that, Tone and Sahoo [108] extended the theoretical SBM model, and added the slacks to modify the constraint for undesirable outputs. It is argued that the DEA-SBM model is more in line with reality than the more traditional models, and is widely used in efficiency evaluations, particularly efficiency evaluations that integrate undesirable outputs $[21,109,110]$. 
This paper established a DEA-SBM model for sustainable innovation efficiency. This DEA-SBM model with undesirable outputs can be formulated as follows:

$$
\begin{aligned}
& \min \theta^{*}=\frac{1-\frac{1}{m} \sum_{i=1}^{n}\left(s_{i}^{-} / x_{i 0}\right)}{1+\frac{1}{s_{1}+s_{2}}\left(\sum_{r=1}^{s_{1}}\left(s_{r}^{g} / y_{r 0}^{g}\right)+\sum_{r=1}^{s_{2}}\left(s_{r}^{b} / y_{r 0}^{b}\right)\right)} \\
& \text { s.t. }\left\{\begin{array}{l}
x_{0}=X \lambda+s_{i}^{-} \\
y_{0}^{g}=y^{g} \lambda-s^{g} \\
y_{0}^{b}=y^{b} \lambda+s^{b} \\
\lambda, s^{-}, s^{g}, s^{b} \geq 0
\end{array}\right.
\end{aligned}
$$

where the vectors $s^{-}, s^{g}$, and $s^{b}$ refer to slack variables of input, desirable output, and undesirable output, respectively, and $\lambda$ is the weight vector. For each DMU, it is efficient when $\theta^{*}=1$ and $s^{-}=s^{g}=s^{b}=0$. When $\theta^{*}<1$, the DMU is inefficient, which means that there is room for improvement in the inputs and outputs.

\subsection{Indicators Selection}

There are 31 administrative regions of provinces, autonomous regions, and municipalities in mainland China. Tibet was excluded in our research for the lack of data available. Our data thus contained 30 regions, which were usually grouped into three areas according to the traditional division, that is, eastern, central, and western China, as shown in Table 2. The eastern China area contains most of the coastal regions with a relatively developed economy, while the central area is China's traditional agricultural base. Western China area is usually seen as an underdeveloped area [111].

Table 2. Areas and regions within China.

\begin{tabular}{cr}
\hline Areas & Regions \\
\hline Eastern China & Beijing, Tianjin, Shanghai, Liaoning, Hebei, Shandong, Jiangsu, Zhejiang, Fujian, Guangdong, Hainan \\
Central China & Heilongiang, Jilin, Inner Mongolia, Henan, Shanxi, Anhui, Hubei, Hunan, Jiangxi, Guangxi \\
Western China & Chongqing, Sichuan, Shaanxi, Yunnan, Gansu, Xinjiang, Guizhou, Qinghai, Ningxia \\
\hline
\end{tabular}

\subsubsection{Inputs}

As a core of the regional innovation system, $R \& D$ activities are often emphasized as the main source of new knowledge, new inventions, technological innovation, and improvement. It is broadly argued that knowledge development, capture, and spillover closely relate to the number of R\&D employees [18]. For the input indicators, R\&D labor and capital were selected according to previous research $[112,113]$. Therefore, $R \& D$ personnel full-time equivalent, $R \& D$ expenditure, and new product development projects were used to serve as input indicators.

\subsubsection{Desirable and Undesirable Outputs}

In our research, output indicators were divided into desirable outputs and undesirable outputs. Invention applications and new product sales were used to represent the desirable outputs. We chose industrial $\mathrm{SO}_{2}$ emissions $[114,115]$ and $\mathrm{CO}_{2}$ emissions [116-118] to represent the undesirable outputs.

\subsection{Data Sources}

China has experienced rapid technological and economic growth since its acceptance to the World Trade Organization (WTO) in 2001. Therefore, we focused our research on the period 2002-2014. Data on R\&D personnel full-time equivalents, R\&D expenditures, new product development projects, invention applications, and new product sales were obtained from the China Statistical Yearbook. $\mathrm{SO}_{2}$ emission data were obtained from China Statistical Yearbook on Environment. Data on regional $\mathrm{CO}_{2}$ emissions were not available in existing data sources. They could be estimated by multiplying 
the amount of energy consumption with their corresponding carbon emission coefficients, with the following equation [119]:

$$
C E=\sum_{i=1}^{n}\left(E_{i} \times F_{i} \times 44 / 12\right) .
$$

In this paper, three main types of fossil fuels were calculated: coal, oil, and natural gas. $C E$ is the quantity of $\mathrm{CO}_{2}$ emissions from these three types of fossil fuels, $i$ denotes the indicator of different fossil fuel types, including coal, oil, and natural gas. $E_{i}$ is the total consumption of fossil fuel, $F_{i}$ is the carbon emission coefficient of fossil fuel $i$. Based on the research results of the Energy Research Institute, the coefficients of coal, oil, and natural gas were assumed to be $0.7329,0.565$, and 0.445 , respectively $[119,120]$. The molecular weight ratio of $\mathrm{CO}_{2}(44)$ to carbon (12) was 44/12. Data on energy consumption were derived from the China Energy Statistical Yearbook. All currency data were converted into real currency (Yuan) at 2002 prices with Gross Domestic Product (GDP) deflators.

Technological innovations need time before being accepted and utilized in society, as frequently observed in various technology diffusion processes [102]. It is necessary to consider the existence of a time lag in the transformation procedure from R\&D inputs to transform into outputs [121-123]. Yet, in the literature, no specific time lag length on innovation outputs has been generally accepted [101,124]. However, there is also no significant difference in the time lag span in innovation evaluation research $[122,125,126]$. We chose to set the time lag as one year [27], which means it takes one year from inputs to outputs.

\section{Efficiency Evaluation of Regional Sustainable Innovation in China}

\subsection{Evaluation Results of Regional Sustainable Innovation Efficiency}

The descriptive statistics for the data of all the input and output variables of China are shown in Table 3.

Table 3. Statistics of input and output variables.

\begin{tabular}{|c|c|c|c|c|c|c|c|}
\hline $\begin{array}{l}\text { Inputs and } \\
\text { outputs }\end{array}$ & Variable & Unit & Mean & Median & Std. dev. & Min & Max \\
\hline \multirow[t]{3}{*}{ Inputs } & $\begin{array}{l}\text { R\&D personnel } \\
\text { full-time } \\
\text { equivalent }\end{array}$ & man-year & $42,600.47$ & 23,007 & $66,674.75$ & 85 & 426,330 \\
\hline & $\begin{array}{c}\text { R\&D } \\
\text { expenditure } \\
\text { new product }\end{array}$ & $\begin{array}{l}10,000 \\
\text { yuan }\end{array}$ & $823,060.84$ & $357,167.31$ & $1,302,598.93$ & 1189.47 & $8,198,557.48$ \\
\hline & $\begin{array}{l}\text { development } \\
\text { projects }\end{array}$ & item & 5785.52 & 2600.5 & 9000.05 & 28 & 62,306 \\
\hline \multirow[t]{2}{*}{$\begin{array}{l}\text { Desirable } \\
\text { outputs }\end{array}$} & $\begin{array}{l}\text { Inventions } \\
\text { application }\end{array}$ & piece & 3310.57 & 777 & 7244.04 & 2 & 55,624 \\
\hline & $\begin{array}{l}\text { New product } \\
\text { sales }\end{array}$ & $\begin{array}{l}10,000 \\
\text { yuan }\end{array}$ & $16,097,473.3$ & $6,708,482.84$ & $23,861,895.6$ & $35,142.21$ & $145,528,075$ \\
\hline \multirow{2}{*}{$\begin{array}{l}\text { Undesirable } \\
\text { outputs }\end{array}$} & $\mathrm{SO}_{2}$ emission & 10,000 tons & 64.12 & 57.01 & 38.55 & 2.12 & 171.5 \\
\hline & $\mathrm{CO}_{2}$ emission & 10,000 tons & $34,011.06$ & $25,855.44$ & $25,675.41$ & 934.02 & $127,948.16$ \\
\hline
\end{tabular}

Using the SBM model with undesirable outputs, the regional sustainable innovation efficiency of 30 regions in mainland China from 2002 to 2014 was obtained, as shown in Table 4. Large values reflect a high sustainable innovation efficiency. The value 1.0000 means that one province was at the efficient frontier that year. We can see from the table that efficiency values differed greatly between provinces and years. 
Table 4. Innovation efficiency of 30 regions, 2002-2014.

\begin{tabular}{|c|c|c|c|c|c|c|c|c|c|c|c|c|c|c|c|}
\hline \multicolumn{2}{|r|}{ Regions } & \multirow{2}{*}{\begin{tabular}{|c|}
2002 \\
0.8926
\end{tabular}} & \multirow{2}{*}{\begin{tabular}{|c|}
2003 \\
1.0000
\end{tabular}} & \multirow{2}{*}{$\begin{array}{c}2004 \\
1.0000\end{array}$} & \multirow{2}{*}{$\begin{array}{c}2005 \\
1.0000\end{array}$} & \multirow{2}{*}{$\begin{array}{c}2006 \\
1.0000\end{array}$} & \multirow{2}{*}{$\begin{array}{c}2007 \\
1.0000\end{array}$} & \multirow{2}{*}{$\begin{array}{c}2008 \\
1.0000\end{array}$} & \multirow{2}{*}{$\begin{array}{c}2009 \\
1.0000\end{array}$} & \multirow{2}{*}{$\begin{array}{c}2010 \\
1.0000\end{array}$} & \multirow{2}{*}{$\begin{array}{c}2011 \\
1.0000\end{array}$} & \multirow{2}{*}{$\begin{array}{c}2012 \\
1.0000\end{array}$} & \multirow{2}{*}{$\begin{array}{c}2013 \\
1.0000\end{array}$} & \multirow{2}{*}{\begin{tabular}{|c|}
2014 \\
1.0000
\end{tabular}} & \multirow{2}{*}{$\begin{array}{l}\text { Mean } \\
0.9917\end{array}$} \\
\hline Eastern & Beijing & & & & & & & & & & & & & & \\
\hline & Tianjin & 1.0000 & 1.0000 & 1.0000 & 1.0000 & 1.0000 & 1.0000 & 0.8807 & 1.0000 & 1.0000 & 0.8366 & 1.0000 & 0.8184 & 1.0000 & 0.9643 \\
\hline & Hebei & 0.1561 & 0.2821 & 0.3081 & 0.3349 & 0.2630 & 0.3369 & 0.3865 & 0.3947 & 0.4580 & 0.5145 & 0.5613 & 0.5818 & 0.5600 & 0.3952 \\
\hline & Liaoning & 0.2032 & 0.3206 & 0.2896 & 0.3089 & 0.3012 & 0.3880 & 0.4760 & 0.4719 & 0.4994 & 0.6136 & 0.6906 & 0.6550 & 0.5902 & 0.4468 \\
\hline & Shanghai & 1.0000 & 1.0000 & 1.0000 & 1.0000 & 1.0000 & 1.0000 & 1.0000 & 1.0000 & 1.0000 & 1.0000 & 1.0000 & 1.0000 & 1.0000 & 1.0000 \\
\hline & Jiangsu & 0.6466 & 0.7164 & 0.4993 & 0.4078 & 1.0000 & 1.0000 & 1.0000 & 1.0000 & 1.0000 & 1.0000 & 1.0000 & 1.0000 & 1.0000 & 0.8669 \\
\hline & Zhejiang & 1.0000 & 1.0000 & 0.5806 & 0.6502 & 1.0000 & 1.0000 & 0.6360 & 0.7406 & 1.0000 & 1.0000 & 1.0000 & 1.0000 & 1.0000 & 0.8929 \\
\hline & Fujian & 1.0000 & 0.3659 & 0.3309 & 0.3639 & 0.3665 & 0.4348 & 0.6101 & 0.7014 & 0.7066 & 0.7137 & 0.6910 & 0.6633 & 0.6813 & 0.5869 \\
\hline & Shandong & 0.5377 & 0.5609 & 0.4867 & 0.4289 & 0.4759 & 0.6205 & 1.0000 & 1.0000 & 1.0000 & 1.0000 & 1.0000 & 1.0000 & 0.7411 & 0.7578 \\
\hline & Guangdong & 1.0000 & 1.0000 & 1.0000 & 1.0000 & 1.0000 & 1.0000 & 1.0000 & 1.0000 & 1.0000 & 1.0000 & 1.0000 & 1.0000 & 1.0000 & 1.0000 \\
\hline & Hainan & 1.0000 & 1.0000 & 1.0000 & 1.0000 & 1.0000 & 1.0000 & 1.0000 & 1.0000 & 1.0000 & 1.0000 & 1.0000 & 1.0000 & 1.0000 & 1.0000 \\
\hline \multirow[t]{10}{*}{ Central } & Shanxi & 0.1151 & 0.1758 & 0.2142 & 0.3009 & 0.3240 & 0.3254 & 0.4048 & 0.5056 & 0.4533 & 0.5806 & 0.6032 & 0.5613 & 0.5515 & 0.3935 \\
\hline & Inner Mongolia & 0.3488 & 0.3058 & 0.4727 & 0.4183 & 0.4175 & 0.5224 & 0.4985 & 0.5786 & 0.4581 & 0.5688 & 0.5985 & 0.5767 & 0.6015 & 0.4897 \\
\hline & Jilin & 0.2516 & 0.2212 & 0.3215 & 1.0000 & 1.0000 & 1.0000 & 1.0000 & 1.0000 & 1.0000 & 1.0000 & 0.5127 & 0.6030 & 1.0000 & 0.7623 \\
\hline & Heilongjiang & 0.2196 & 0.2251 & 0.2382 & 0.2923 & 0.2372 & 0.3090 & 0.2927 & 0.3341 & 0.3247 & 0.3999 & 0.4831 & 0.4643 & 0.4500 & 0.3285 \\
\hline & Anhui & 0.2030 & 0.2926 & 0.2751 & 0.4170 & 0.4970 & 0.4887 & 0.5782 & 0.6398 & 0.6668 & 0.7829 & 1.0000 & 1.0000 & 1.0000 & 0.6032 \\
\hline & Jiangxi & 0.1484 & 0.1513 & 0.3138 & 0.2856 & 0.2328 & 0.2540 & 0.3464 & 0.4576 & 0.4676 & 0.5486 & 0.6861 & 0.6529 & 0.6621 & 0.4006 \\
\hline & Henan & 0.2431 & 0.3182 & 0.3034 & 0.4277 & 0.4191 & 0.4602 & 0.4709 & 0.4767 & 0.4900 & 0.5023 & 0.6231 & 0.5827 & 0.6116 & 0.4561 \\
\hline & Hubei & 0.1781 & 0.3369 & 0.3228 & 0.4374 & 0.4464 & 0.5020 & 0.5819 & 0.5775 & 0.5458 & 0.6101 & 0.7503 & 0.7209 & 0.7323 & 0.5186 \\
\hline & Hunan & 0.3671 & 0.4873 & 0.3971 & 0.5323 & 0.5933 & 0.4791 & 0.7518 & 0.7212 & 0.7546 & 1.0000 & 1.0000 & 1.0000 & 1.0000 & 0.6988 \\
\hline & Guangxi & 0.3154 & 0.3062 & 0.4694 & 0.3400 & 0.5528 & 0.5491 & 0.5347 & 0.5423 & 0.5035 & 0.5526 & 0.7394 & 0.6965 & 0.7217 & 0.5249 \\
\hline \multirow[t]{9}{*}{ Western } & Chongqing & 0.2734 & 0.2936 & 0.4018 & 0.5661 & 0.6351 & 0.5977 & 0.6762 & 1.0000 & 1.0000 & 0.7958 & 0.7876 & 1.0000 & 1.0000 & 0.6944 \\
\hline & Sichuan & 0.3722 & 0.3417 & 0.2849 & 0.4841 & 0.4623 & 0.4554 & 0.5537 & 0.5962 & 0.5613 & 0.6410 & 0.6684 & 0.6687 & 0.6826 & 0.5210 \\
\hline & Guizhou & 0.2175 & 0.2457 & 0.3316 & 0.5081 & 0.4679 & 0.5294 & 0.4409 & 0.6000 & 0.5397 & 0.6079 & 0.6196 & 1.0000 & 0.6495 & 0.5198 \\
\hline & Yunnan & 0.2765 & 0.3614 & 0.4389 & 0.3946 & 0.6445 & 0.5547 & 0.4543 & 0.5434 & 0.5596 & 0.6153 & 0.6202 & 0.6185 & 0.5988 & 0.5139 \\
\hline & Shaanxi & 0.1387 & 0.1541 & 0.2717 & 0.3358 & 0.3564 & 0.3712 & 0.4186 & 0.4783 & 0.4442 & 0.4681 & 0.5246 & 0.5080 & 0.4602 & 0.3792 \\
\hline & Gansu & 0.2005 & 0.1903 & 0.4527 & 0.5029 & 0.4037 & 0.4314 & 0.3426 & 0.4643 & 0.4259 & 0.6209 & 0.5696 & 0.6235 & 0.5429 & 0.4439 \\
\hline & Qinghai & 0.0990 & 0.1291 & 1.0000 & 0.3996 & 0.4770 & 0.4735 & 0.5363 & 1.0000 & 1.0000 & 1.0000 & 1.0000 & 1.0000 & 1.0000 & 0.7011 \\
\hline & Ningxia & 0.3744 & 0.2344 & 0.3709 & 0.3087 & 0.2064 & 0.3141 & 0.3572 & 0.4937 & 0.4906 & 0.6201 & 0.6988 & 0.6172 & 1.0000 & 0.4682 \\
\hline & Xinjiang & 0.2624 & 0.4562 & 0.2746 & 0.3456 & 0.3844 & 0.5349 & 0.4447 & 0.5957 & 0.5641 & 0.5762 & 0.6623 & 1.0000 & 0.6940 & 0.5227 \\
\hline
\end{tabular}


The average values of this table are plotted for all provinces in Figure 1.

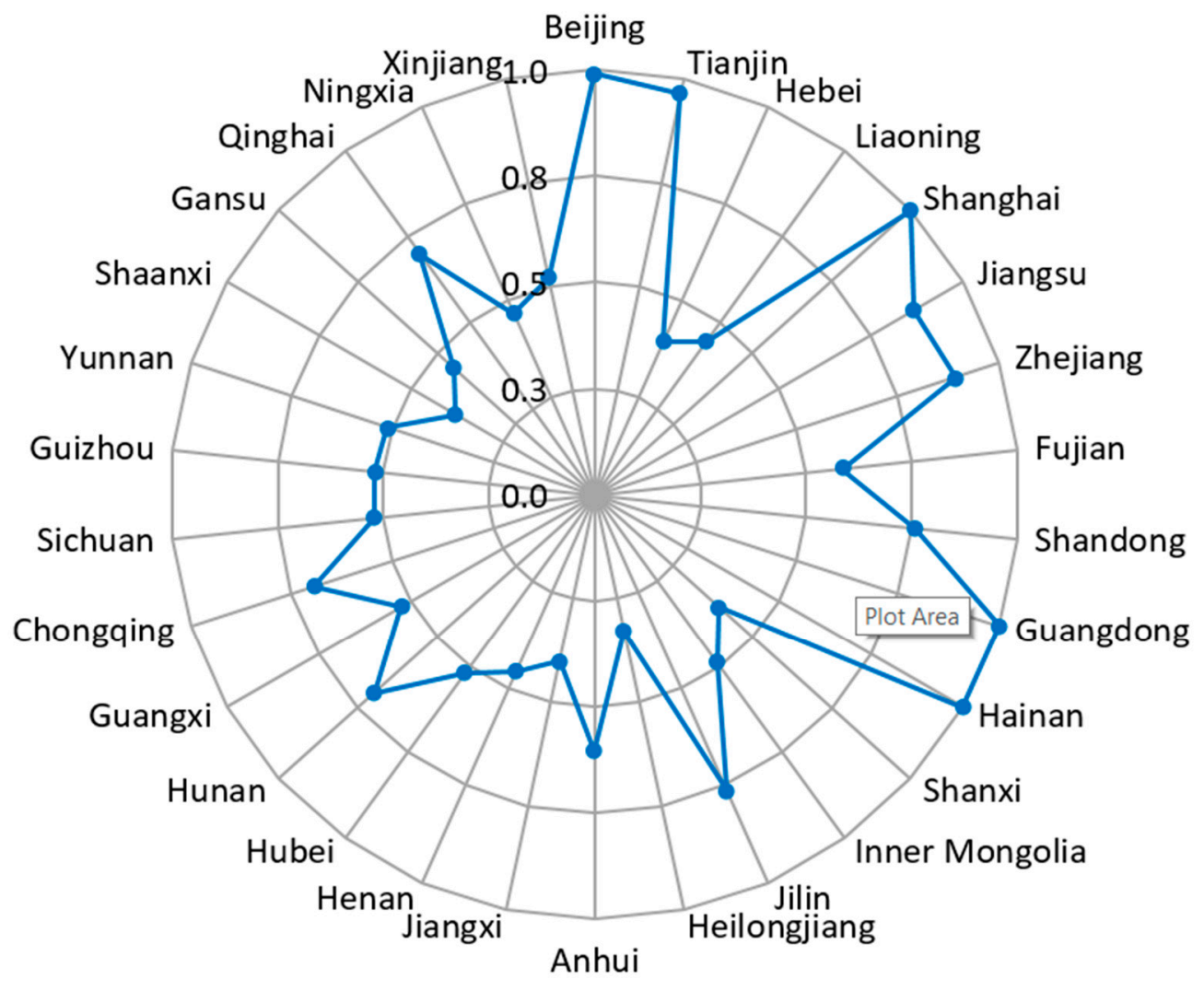

Figure 1. Average efficiency in 30 provinces.

From Table 4 and Figure 1 it can be seen that most provinces showed an increasing sustainable innovation efficiency through the years. In addition, the sustainable innovation efficiency among provinces differed significantly. There was only a small percentage of overall sustainably innovative efficient regions, which constituted the forefront of sustainable innovation efficiency in China. As China's economic and innovation center, the innovation efficiency of Shanghai and Guangdong was always 1, from 2002 up until 2014, which has a close connection with their front running position in technological innovation, relative to the other provinces. Hainan's innovation efficiency was also 1 through the whole period under study, as it attaches great importance to environmental protection and policy regulation [127].

Beijing and Tianjin showed values higher than 0.9 for the whole period, and they are more influenced by the government's environmental protection policy [128] and the Beijing-Tianjin-Hebei coordinated development strategy [129]. Zhejiang and Jiangsu showed higher values than 0.8 for the whole period of 2002-2014, with well-established social systems and developed economical institutions. Table 2 indicates that the provinces with the highest sustainable innovation efficiencies were all the provinces in eastern China. These provinces either have good environmental protection institutions available, or have access to more advanced technologies and state-of-the-art industrial production processes with a relatively low energy consumption.

A total of 19 provinces had a sustainable innovation efficiency value that ranged from 0.4 to 0.8-Jilin, Shandong, Qinghai, Hunan, Chongqing, Anhui, Fujian, Guangxi, Xinjiang, Sichuan, Guizhou, Hubei, Yunnan, Inner Mongolia, Ningxia, Henan, Liaoning, Gansu, and Jiangxi. Most of these provinces are in central and western China, and are subject to a process of increasing urbanization and industrialization. Moreover, these provinces have relatively underdeveloped economies, educational 
resources, and show lower levels of technological innovation. For example, Henan, Anhui, Hunan, and Hubei are all traditional agricultural provinces.

It is noteworthy that four provinces had the lowest efficiency, lower than 0.40 , and were at the bottom of the ranking; these were Heilongjiang, Shaanxi, Shanxi, and Hebei. Heilongjiang is a typical oil-producing province and also an old industrial province in China, while Hebei is an iron- and steel-producing province. Both Shaanxi and Shanxi are China's major coal-producing provinces. All these four provinces are China's traditional resource-producing and fossil energy-consuming provinces, with natural energy resource-intensive industries; they do not have many universities and innovative companies. Relying on abundant local resources, they have adopted a heavy industry-oriented economic development mode, such as coal mining, and steel and cement production, which brings seriously lower environmental scores.

\subsection{Regional Comparative Analysis}

In order to analyze the regional innovation efficiency from the viewpoint of a larger scale, we further shed light on the east, west, and central areas of China. To further reflect the differences between these three areas, each area's sustainable innovation efficiency is shown in Table 5 and Figure 2.

Table 5. Sustainable innovation efficiency of three areas, 2002-2014.

\begin{tabular}{cllllllllllllll}
\hline Area & $\mathbf{2 0 0 2}$ & $\mathbf{2 0 0 3}$ & $\mathbf{2 0 0 4}$ & $\mathbf{2 0 0 5}$ & $\mathbf{2 0 0 6}$ & $\mathbf{2 0 0 7}$ & $\mathbf{2 0 0 8}$ & $\mathbf{2 0 0 9}$ & $\mathbf{2 0 1 0}$ & $\mathbf{2 0 1 1}$ & $\mathbf{2 0 1 2}$ & $\mathbf{2 0 1 3}$ & $\mathbf{2 0 1 4}$ & Mean \\
\hline Eastern & 0.7669 & 0.7496 & 0.6814 & 0.6813 & 0.7642 & 0.7982 & 0.8172 & 0.8462 & 0.8785 & 0.8799 & 0.9039 & 0.8835 & 0.8702 & 0.8093 \\
Central & 0.2390 & 0.2820 & 0.3328 & 0.4452 & 0.4720 & 0.4890 & 0.5460 & 0.5833 & 0.5664 & 0.6546 & 0.6996 & 0.6858 & 0.7331 & 0.5176 \\
Western & 0.2461 & 0.2674 & 0.4252 & 0.4273 & 0.4486 & 0.4736 & 0.4694 & 0.6413 & 0.6206 & 0.6606 & 0.6835 & 0.7818 & 0.7365 & 0.5294 \\
$\begin{array}{c}\text { Whole } \\
\text { cuuntry }\end{array}$ & 0.4347 & 0.4491 & 0.4883 & 0.5264 & 0.5721 & 0.5977 & 0.6225 & 0.6971 & 0.6971 & 0.7390 & 0.7697 & 0.7871 & 0.7844 & 0.6281 \\
\hline
\end{tabular}

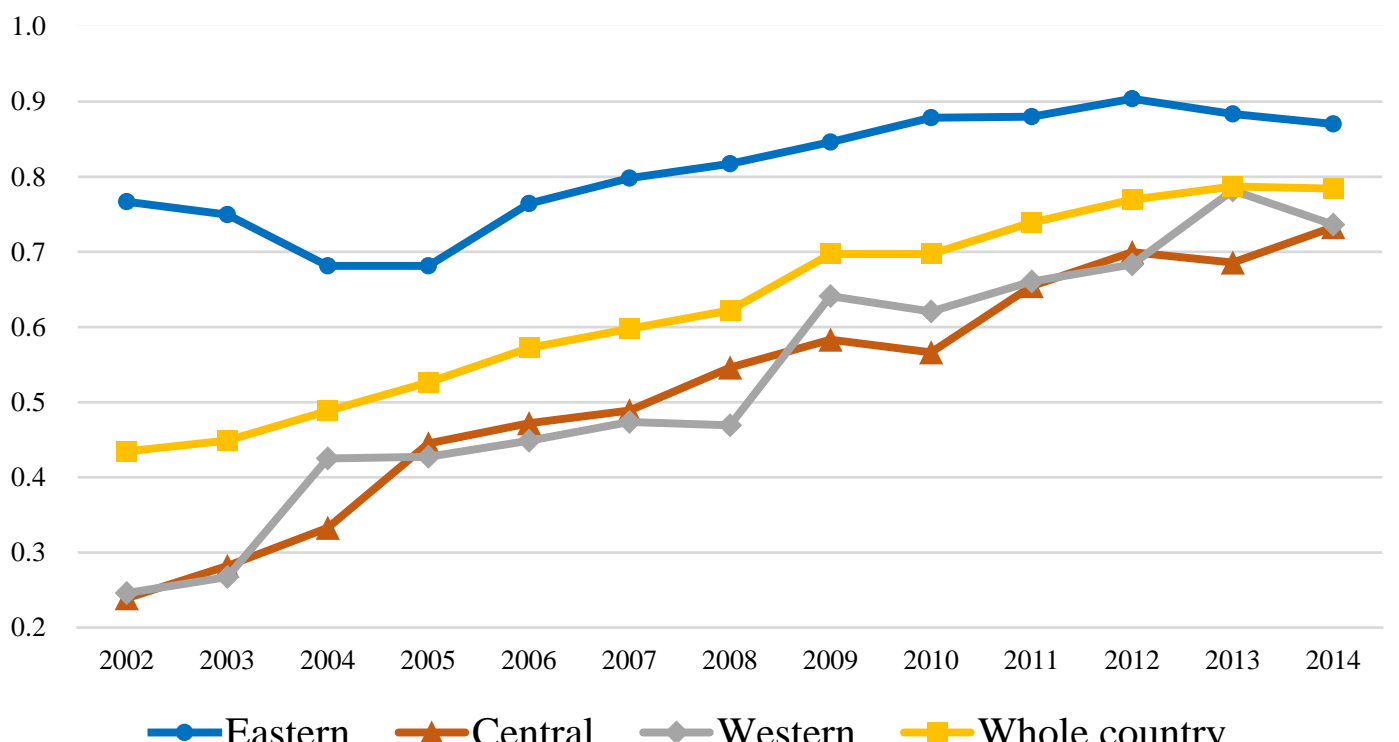

Figure 2. Regional sustainable innovation efficiency (2002-2014).

We can see from Figure 2 that the sustainable innovation efficiency of China has essentially been rising since 2002, from a lower value 0.4347 in 2002 to the higher value 0.7844 in 2014, demonstrating China's constant efforts in innovation investment, environmental protection, energy conservation, and reduction of carbon emissions. However, the average sustainable innovation efficiency value of China from 2002 to 2014 was 0.6281 , which means there is still much more potential.

The innovation efficiency in eastern China was always much higher than the central area and western area, with an average innovation efficiency value of 0.8093 . Central and western areas had 
similar innovation efficiency scores in this period, with mean values of 0.5176 and 0.5294 , respectively, while showing slow growth trends. Compared with the sustainable innovation efficiency score of the country as a whole, eastern China scored much higher than the national level; the central area and western areas showed considerably lower scores compared to the national level. We can clearly see that eastern area is the main force of promoting technological innovation development in China. The central and western areas lag behind in technological innovation. The results thus indicate that the economically developed eastern area has a higher sustainable innovation efficiency, while the less developed central and western areas achieve a lower sustainable innovation efficiency.

To clearly manifest the regional disparities, we further drew the figure of regional sustainable innovation efficiency gaps. The regional efficiency gap was obtained by subtracting the efficiency values of the two regions. For example, the efficiency gap of "eastern-central" was derived from the efficiency value of the eastern area minus the efficiency value of the central area. Seen from Figure 3, the sustainable innovation efficiency gaps of "eastern-central" and "eastern-western" showed similar decreasing trends, from 0.6 to 0.1. There were large efficiency gaps in 2002 between eastern and backward regions, but by the year 2014, these gaps reduced considerably. The sustainable innovation efficiency gap between central and western areas changed subtly, always in the narrow range of 0.1 to -0.1 . The results show that the efficiency of sustainable innovation in central and western China is increasing, and the regional disparities between east China on the one hand and central and west China on the other are decreasing.

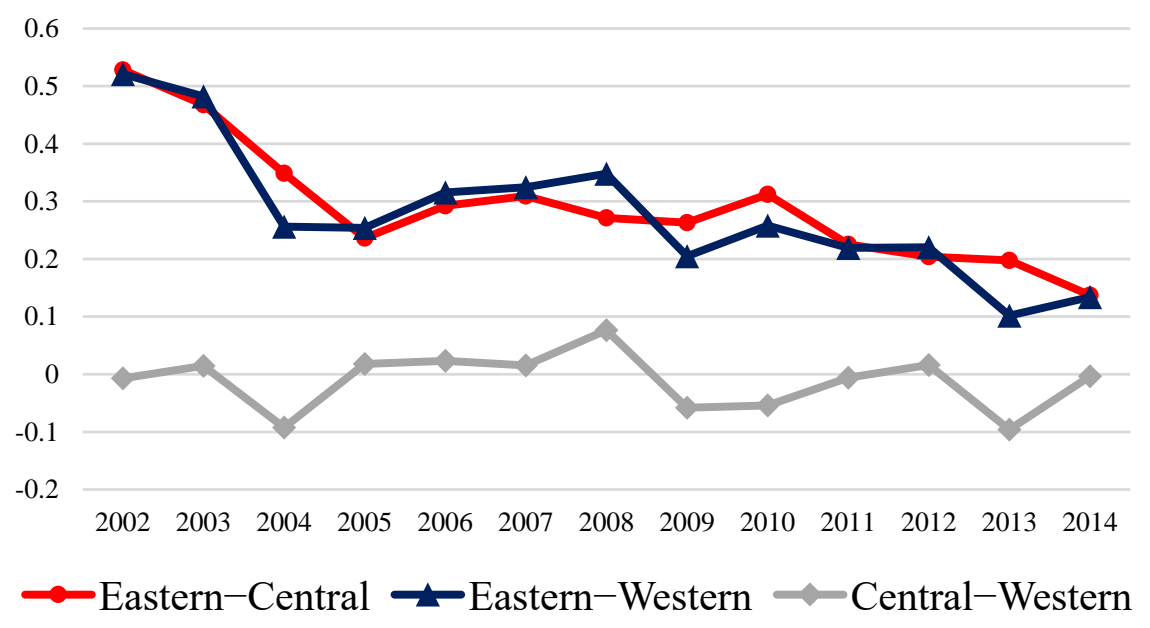

Figure 3. Regional sustainable innovation efficiency gaps (2002-2014).

\subsection{Comparative Analysis with BCC Model Results}

We also made innovation efficiency comparisons with and without undesirable outputs. The average innovation efficiency without undesirable outputs was calculated by using the traditional DEA method (BCC model). Through the BCC model, we could only estimate innovation efficiency without undesirable outputs. The results are quite similar to the above results calculated by the SBM model. The innovation efficiency value of the whole country was 0.43 . The eastern area had the highest efficiency value among the three areas-0.79. The central and western areas had the same efficiency value of 0.33 , which was significantly lower than the national level. Figure 4 shows the average innovation efficiency of the three areas from 2002 to 2014, with and without considering undesirable outputs. When undesirable outputs were taken into consideration, innovation efficiency dropped significantly compared with the SBM model, with reductions of $22 \%, 38 \%$, and $34 \%$, respectively, in eastern, central, and western China. The innovation efficiency value of the whole country decreased by $28 \%$, from 0.60 to 0.43 . However, there were still regional disparities among the three areas, although there was no significant change compared to the results calculated by the SBM model. 


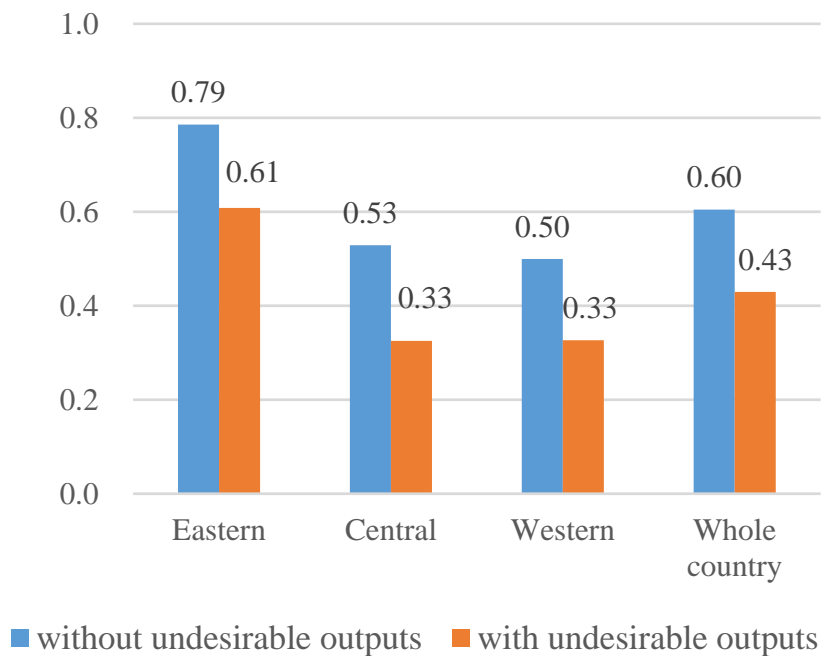

Figure 4. Innovation efficiency with and without undesirable outputs.

\section{Discussion}

\subsection{Hypotheses}

Based on the literature, five hypotheses on regional sustainable innovation efficiency were posited (see Table 1). We tested our hypotheses by applying a DEA-SBM model. According to our empirical results, sustainable innovation efficiency differs greatly among the 30 Chinese regions, varying from 0.3 to 1 . Our model showed that only a few provinces in eastern China are sustainably innovation efficient, while most provinces in central and western China have a medium, to low, to very low sustainable innovation efficiency. This is in line with previous research $[19,21,27,101]$. Eastern China always showed a higher innovation efficiency than central and western areas. We found that provinces with a higher economic development, advanced technologies, and good environmental protection usually had a higher innovation efficiency, which was consistent with most previous research, both in China and abroad [5,8]. All these findings confirm the predictions of Hypothesis 1 and 4 . The sustainable innovation efficiency of the country as a whole showed a rising trend during the years 2002-2014. Hypothesis 3 was modestly confirmed. The results revealed that innovation efficiency dropped considerably when undesirable outputs were considered. Hypothesis 2 was strongly supported. Previous research evaluated regional innovation efficiency with traditional methods, and without taking undesirable outcomes into account, and because of this always got high innovation efficiency values $[7,122,130,131]$. Our results show that integrating undesirable outcomes into the equation brings a more nuanced picture; a picture of sustainable innovation efficiency instead of innovation efficiency. The sustainable innovation efficiency disparities among the three areas were still significant. Moreover, it showed slightly decreasing trends, which lead to the rejection of Hypothesis 5.

\subsection{Contribution to Theory}

To complement previous research, this study provides insight into sustainable innovation efficiency, and a DEA-SBM model was presented to study sustainable innovation efficiency in 30 provinces in China. This research's contribution to regional innovation theory is that it confirms that the concept of the regional innovation system is useful to study differences in parts of a national innovation system, as well as to aggregate the outcomes of different regional innovation systems to the level of the national innovation system [33]. The outcomes showed that the regional innovation system affects the quality and efficiency of the national innovation system greatly [40]. Regional innovation systems are, on the one hand, independently functioning, but on the other hand, they are associated with each other, together forming a bigger entity (cf. [14]). This research also specifies the uniqueness of and differences 
between regional innovation systems [36]. It confirmed that areas with higher industry agglomerations have a relatively high sustainable innovation performance [39].

This research supplements research that concentrates on the relationship between innovation inputs and desirable outputs [95], by means of taking into account the undesirable outputs too. Higher innovation inputs often lead to higher desirable outputs, but when undesirable outputs are integrated into the equation, regional sustainable innovation efficiency is considerably lower for a region compared to its more general innovation efficiency score [65].

Another contribution is that this study applied the DEA-SBM model in innovation efficiency research. All the previous research on innovation efficiency either used stochastic frontier analysis or traditional DEA methods [122,131], but none have used the DEA-SBM model. The DEA-SBM model can deal with undesirable outputs effectively.

\subsection{Implications for Practice}

This research compared the efficiency of eastern, central, and western China, and analyzed regional sustainable innovation efficiency at the macro level. China has a large national innovation system [31], which can be grouped into three areas. Seen from the input and output indicators, there are significant performance inequalities [50]. Due to the differences in regional sustainable innovation efficiency across the whole country, the Chinese central government should attach great importance to regional disparities. On the other hand, China is an enormous big country with different regional social-economic developmental levels. Policy makers in each province could formulate provincial policies in light of the specific features and characteristics of their province. There is huge potential to be tapped. In combination with the Western Development Strategy and the "One Belt, One Road" construction, it will inject vitality into the economic development of the central and western regions, providing financial and technical support to promote innovation efficiency. In addition, regional coordinated development could be accelerated to narrow cross-regional differences.

\subsection{Limitations}

This research had several limitations. This paper just analyzed the influencing factors of sustainable innovation efficiency from a quantitative perspective. This may lead to one-sided analytical results. The DEA method cannot measure the influence of random errors on efficiency, such as environmental factors, while it attributes the uncontrollable factors and statistical errors to inefficiency. This will affect the estimation results to a certain extent, resulting in relatively low efficiency values. Sustainability consists of economic, societal, and environmental aspects. The efficiency calculated by the SBM model is between 0 and 1 . If the DMU efficiency values are all of the same efficient value, 1 , the relative efficiency cannot be further compared. The SBM model has the same limitation as the traditional DEA models.

This research lacked broader sustainability considerations covering economic and social indicators, since energy consumption and environmental pollutions are the central issues in this study. Many other indicators can also represent sustainable innovation performance. We used limited input as well as output indicators. Due to the data availability and the reason that the number of DMUs should be more than three times the number of indicators in the DEA method, we could just choose three input indicators and four output indicators.

\subsection{Further Research}

China's sustainable innovation efficiency is still relatively low. Both internal and external environmental factors lead to this inefficiency. More specifically, regional environment, industrial policy, ownership, corporate governance, firm size, and financing restrictions can affect innovation efficiency to some extent $[26,132,133]$. This research was the first attempt to stress the undesirable outputs in regional innovation efficiency, and by doing this, calculated regional sustainable innovation 
efficiency. Future research could pay special attention to the relationship of spatial spillover effects and industrial agglomeration effects and sustainable innovation efficiency.

Our findings showed significant differences of regional sustainable innovation efficiency on the province level due to the specific features of each province. Every province in China is composed of many prefecture-level cities with different developments. For example, there is a huge gap in economic development and technological innovation between southern and northern cities in the Jiangsu province. Future research could further this research approach to the city level to better explain the differences in sustainable innovation efficiency within regions and in technological innovation. Meanwhile, China has many well-developed economic areas, such as the Yangtze River Delta, the Pearl River Delta, and the Beijing-Tianjin-Hebei areas. It could be meaningful to also focus future research on these urban clusters, since the Chinese government is vigorously promoting the development of these urban clusters. Our research stressed the regional innovation efficiency with undesirable outputs. China has many industrial sectors where technological development, energy consumption, and environmental pollution vary widely among the sectors. It could also be worthwhile to extend this research to these sectors of Chinese industry, such as the power sector, the pharmaceutical sector, and construction sectors.

\section{Conclusions and Implications}

In conclusion, this research evaluated and compared the status and trends of regional sustainable innovation efficiency in 30 regions in China, from 2002 to 2014, based on the application of a DEA-SBM model. Evaluation results demonstrate that the sustainable innovation efficiency of China on a national level increased in this period, from 0.4347 in 2002 to 0.7844 in 2014, while the sustainable innovation efficiency differs widely across subnational regions. Most of the eastern provinces showed relatively high sustainably efficiencies, while many provinces in central and western China showed medium, to low, to very low sustainable innovation efficiency scores, indicating that sustainable technological innovation in the central and western areas are much lower than the eastern area. The eastern region remains the leader in China's technological innovation. However, regional disparities between the three areas have decreased to lower levels in recent years. Chinese regions show higher innovation efficiency scores when undesirable outputs are not taken into account, and show significantly lower innovation efficiency scores when undesirable outputs are taken into account. From the viewpoint of environmental sustainability it is worth paying more attention to the issues of undesirable outputs.

The central government of China could attach greater importance to the improvement of sustainable innovation efficiency in its regions, especially the central and western regions. Improved governance of sustainability could drive and support the improvement of sustainable innovation efficiency. The ongoing call for more sustainably functioning Chinese corporations and industries initiates more consideration for how to rationally use scientific and technological resources to increase desirable outputs, while at the same time reduce undesirable outputs. In addition, China's central government's investment policy can benefit from not just focusing on the eastern area, but also on the central and western areas. Increasing scientific and technological investments in the central and western areas may greatly contribute to China's increase in sustainable innovation efficiency.

Author Contributions: Conceptualization, K.X., B.B. and Q.C.; Data curation, K.X.; Formal analysis, K.X. and B.B.; Funding acquisition, B.B. and Q.C.; Methodology, K.X.; Project administration, B.B. and Q.C.; Resources, B.B. and Q.C.; Supervision, B.B. and Q.C.; Validation, B.B. and Q.C.; Visualization, K.X.; Writing-original draft, K.X.; Writing-review \& editing, B.B. and Q.C. All authors have read and agreed to the published version of the manuscript.

Funding: This research received no external funding.

Acknowledgments: The authors would like to thank the editor and anonymous reviewers for their insightful comments and suggestions.

Conflicts of Interest: The authors declare no conflict of interest. 


\section{References}

1. Asheim, B.T.; Gertler, M.S. The Oxford Handbook of Innovation; Oxford University Press: Oxford, UK, 2009.

2. Mas-Verdú, F.; Ortiz-Miranda, D.; García-Álvarez-Coque, J.M. Examining organizational innovations in different regional settings. J. Bus. Res. 2016, 69, 5324-5329. [CrossRef]

3. Hamidi, S.; Zandiatashbar, A.; Bonakdar, A. The relationship between regional compactness and regional innovation capacity (RIC): Empirical evidence from a national study. Technol. Forecast. Soc. Chang. 2019, 142, 394-402. [CrossRef]

4. Tojeiro-Rivero, D.; Moreno, R. Technological cooperation, R\&D outsourcing, and innovation performance at the firm level: The role of the regional context. Res. Policy 2019, 48, 1798-1808.

5. Li, Z.; Li, J.; He, B. Does foreign direct investment enhance or inhibit regional innovation efficiency? Chin. Manag. Stud. 2018, 12, 35-55. [CrossRef]

6. Han, U.; Asmild, M.; Kunc, M. Regional R\&D Efficiency in Korea from Static and Dynamic Perspectives. Reg. Stud. 2014, 50, 1170-1184.

7. Broekel, T.; Rogge, N.; Brenner, T. The innovation efficiency of German regions-A shared-input DEA approach. Rev. Reg. Res. 2017, 38, 77-109. [CrossRef]

8. Bai, J. On Regional Innovation Efficiency: Evidence from Panel Data of China's Different Provinces. Reg. Stud. 2013, 47, 773-788. [CrossRef]

9. Wang, S.; Fan, J.; Zhao, D.; Wang, S. Regional innovation environment and innovation efficiency: The Chinese case. Technol. Anal. Strateg. Manag. 2015, 28, 396-410. [CrossRef]

10. Clow, M. The natural limits of technological innovation. Technol. Soc. 1998, 20, 141-156. [CrossRef]

11. NBSC (National Bureau of Statistics of China). Statistical Communiqué of the People's Republic of China on the 2018 National Economic and Social Development. Available online: http://www.stats.gov.cn/english/ PressRelease/201902/t20190228_1651335.html (accessed on 13 June 2019).

12. Li, X. China's regional innovation capacity in transition: An empirical approach. Res. Policy 2009, 38, 338-357. [CrossRef]

13. Freeman, C. Technology Policy and Economic Performance: Lessons from Japan; Pinter: London, UK, 1987.

14. Cooke, P. Regional innovation systems: Competitive regulation in the new Europe. Geoforum 1992, 23, 365-382. [CrossRef]

15. Asheim, B.T.; Isaksen, A. Regional Innovation Systems- The Integration of Local 'Sticky' and Global 'Ubiquitous' Knowledge. J. Technol. Transf. 2002, 27, 77-86. [CrossRef]

16. Autio, E. Evaluation of RTD in regional systems of innovation. Eur. Plan. Stud. 1998, 6, 131-140. [CrossRef]

17. Cooke, P.; Gomez Uranga, M.; Etxebarria, G. Regional innovation systems: Institutional and organisational dimensions. Res. Policy 1997, 26, 475-491. [CrossRef]

18. Fritsch, M.; Slavtchev, V. Determinants of the Efficiency of Regional Innovation Systems. Reg. Stud. 2011, 45, 905-918. [CrossRef]

19. Chen, K.; Guan, J. Measuring the Efficiency of China's Regional Innovation Systems: Application of Network Data Envelopment Analysis (DEA). Reg. Stud. 2012, 46, 355-377. [CrossRef]

20. Broekel, T. Collaboration Intensity and Regional Innovation Efficiency in Germany-A Conditional Efficiency Approach. Ind. Innov. 2012, 19, 155-179. [CrossRef]

21. Wang, W.; Yu, B.; Yan, X.; Yao, X.; Liu, Y. Estimation of innovation's green performance: A range-adjusted measure approach to assess the unified efficiency of China's manufacturing industry. J. Clean. Prod. 2017, 149, 919-924. [CrossRef]

22. Chen, C.; Han, J.; Fan, P. Measuring the Level of Industrial Green Development and Exploring Its Influencing Factors: Empirical Evidence from China's 30 Provinces. Sustainability 2016, 8, 153. [CrossRef]

23. IEA. $\mathrm{CO}_{2}$ Emissions from Fuel Combustion-Highlights 2014; IEA Publication: Paris, France, 2014.

24. Liobikienè, G.; Butkus, M. The European Union possibilities to achieve targets of Europe 2020 and Paris agreement climate policy. Renew. Energy 2017, 106, 298-309. [CrossRef]

25. Zhou, K.; Li, Y. Carbon finance and carbon market in China: Progress and challenges. J. Clean. Prod. 2019, 214, 536-549. [CrossRef]

26. Song, M.; Wang, S.; Sun, J. Environmental regulations, staff quality, green technology, R\&D efficiency, and profit in manufacturing. Technol. Forecast. Soc. Chang. 2018, 133, 1-14. 
27. Chen, X.; Liu, Z.; Zhu, Q. Performance evaluation of China's high-tech innovation process: Analysis based on the innovation value chain. Technovation 2018, 74, 42-53. [CrossRef]

28. OECD. National Innovation Systems; OECD Publications: Paris, France, 1997.

29. Nelson, R. National Innovation Systems: A Comparative Analysis; Oxford University Press: Oxford, UK, 1993.

30. Porter, M.E. Clusters and the new economics of competition. Harv. Bus. Rev. 1998, 76, 77-90.

31. OECD. OECD Reviews of Innovation Policy: China; OECD: Paris, France, 2008.

32. Lundvall, B. National Systems of Innovation: Towards a Theory of Innovation and Interactive Learning; Pinter: London, UK, 1992.

33. Cooke, P.; Boekholt, P.; Schall, N.; Schienstock, G. Regional innovation systems: Concepts, analysis and typology. In Proceedings of the EU-RESTPOR Conference "Global Comparison of Regional RTD and Innovation Strategies for Development and Cohesion", Brussels, Beigium, 19-21 September 1996.

34. Zhao, S.L.; Cacciolatti, L.; Lee, S.H.; Song, W. Regional collaborations and indigenous innovation capabilities in China: A multivariate method for the analysis of regional innovation systems. Technol. Forecast. Soc. 2015, 94, 202-220. [CrossRef]

35. Buesa, M.; Heijs, J.; Martínez Pellitero, M.; Baumert, T. Regional systems of innovation and the knowledge production function: The Spanish case. Technovation 2006, 26, 463-472. [CrossRef]

36. Audretsch, D.B.; Feldman, M.P. R\&D spillovers and the geography of innovation and production. Am. Econ. Rev. 1996, 86, 630-640.

37. Jaffe, A.B.; Trajtenberg, M.; Henderson, R. Geographic Localization of Knowledge Spillovers as Evidenced by Patent Citations. Q. J. Econ. 1993, 108, 577-598. [CrossRef]

38. Porter, M.E. The Competitive Advantage of Nations. Harv. Bus. Rev. 1990, 68, 73-93.

39. Maskell, P. Localised learning and industrial competitiveness. Camb. J. Econ. 1999, 23, 167-185. [CrossRef]

40. Chung, S. Building a national innovation system through regional innovation systems. Technovation 2002, 22, 485-491. [CrossRef]

41. Granstrand, O.; Holgersson, M. Innovation ecosystems: A conceptual review and a new definition. Technovation 2019. [CrossRef]

42. Chen, L.-C. Building extra-regional networks for regional innovation systems: Taiwan's machine tool industry in China. Technol. Forecast. Soc. 2015, 100, 107-117. [CrossRef]

43. Moodysson, J.; Zukauskaite, E. Institutional Conditions and Innovation Systems: On the Impact of Regional Policy on Firms in Different Sectors. Reg. Stud. 2012, 48, 127-138. [CrossRef]

44. Lau AK, W.; Lo, W. Regional innovation system, absorptive capacity and innovation performance: An empirical study. Technol. Forecast. Soc. 2015, 92, 99-114. [CrossRef]

45. Belussi, F.; Sammarra, A.; Sedita, S.R. Learning at the boundaries in an "Open Regional Innovation System": A focus on firms' innovation strategies in the Emilia Romagna life science industry. Res. Policy 2010, 39, 710-721. [CrossRef]

46. Yi, S.; Xiao-li, A. Application of threshold regression analysis to study the impact of regional technological innovation level on sustainable development. Renew. Sustain. Energy Rev. 2018, 89, 27-32. [CrossRef]

47. Sun, Y.; Liu, F. A regional perspective on the structural transformation of China's national innovation system since 1999. Technol. Forecast. Soc. 2010, 77, 1311-1321. [CrossRef]

48. Williams, R.; Graham, I.; Jakobs, K.; Lyytinen, K. China and Global ICT standardisation and innovation. Technol. Anal. Strateg. Manag. 2011, 23, 715-724. [CrossRef]

49. Lemoine, F.; Poncet, S.; Ünal, D. Spatial rebalancing and industrial convergence in China. China Econ. Rev. 2015, 34, 39-63. [CrossRef]

50. Lee, J. Changes in the source of China's regional inequality. China Econ. Rev. 2000, 11, 232-245. [CrossRef]

51. Cheong, T.S.; $\mathrm{Wu}, \mathrm{Y}$. The impacts of structural transformation and industrial upgrading on regional inequality in China. China Econ. Rev. 2014, 31, 339-350. [CrossRef]

52. Li, C.; Gibson, J. Rising Regional Inequality in China: Fact or Artifact? World Dev. 2013, 47, 16-29. [CrossRef]

53. Chen, A. Reducing China's regional disparities: Is there a growth cost? China Econ. Rev. 2010, 21, 2-13. [CrossRef]

54. Wang, Y.; Sutherland, D.; Ning, L.; Pan, X. The evolving nature of China's regional innovation systems: Insights from an exploration-exploitation approach. Technol. Forecast. Soc. 2015, 100, 140-152. [CrossRef]

55. Li, J.; Sutherland, D.; Ning, L.; Wang, Y. Firm ownership, industrial structure, and regional innovation performance in China's provinces. Technol. Anal. Strateg. Manag. 2014, 26, 1001-1022. [CrossRef] 
56. Jiao, H.; Zhou, J.; Gao, T.; Liu, X. The more interactions the better? The moderating effect of the interaction between local producers and users of knowledge on the relationship between R\&D investment and regional innovation systems. Technol. Forecast. Soc. 2016, 110, 13-20.

57. Li, X. Specialization, institutions and innovation within China's regional innovation systems. Technol. Forecast. Soc. 2015, 100, 130-139. [CrossRef]

58. Gao, X.; Guo, X.; Sylvan, K.J.; Guan, J. The Chinese innovation system during economic transition: A scale-independent view. J. Informetr. 2010, 4, 618-628. [CrossRef]

59. Franceschini, S.; Faria, L.G.D.; Jurowetzki, R. Unveiling scientific communities about sustainability and innovation. A bibliometric journey around sustainable terms. J. Clean. Prod. 2016, 127, 72-83. [CrossRef]

60. Gerstlberger, W. Regional innovation systems and sustainability-Selected examples of international discussion. Technovation 2004, 24, 749-758. [CrossRef]

61. Charmondusit, K.; Gheewala, S.H.; Mungcharoen, T. Green and sustainable innovation for cleaner production in the Asia-Pacific region. J. Clean. Prod. 2016, 134, 443-446. [CrossRef]

62. Sun, Q. Empirical research on coordination evaluation and sustainable development mechanism of regional logistics and new-type urbanization: A panel data analysis from 2000 to 2015 for Liaoning Province in China. Environ. Sci. Pollut. Res. Int. 2017, 24, 14163-14175. [CrossRef] [PubMed]

63. Yin, H.; He, Q.; Guo, T.; Zhu, J.; Yu, B. Measurement Method and Empirical Research on the Sustainable Development Capability of a Regional Industrial System Based on Ecological Niche Theory in China. Sustainability 2014, 6, 8485-8509. [CrossRef]

64. Baregheh, A.; Rowley, J.; Sambrook, S. Towards a multidisciplinary definition of innovation. Manag. Decis. 2009, 47, 1323-1339. [CrossRef]

65. Saunila, M.; Ukko, J.; Rantala, T. Sustainability as a driver of green innovation investment and exploitation. J. Clean. Prod. 2018, 179, 631-641. [CrossRef]

66. Fernández, Y.F.; López, M.F.; Blanco, B.O. Innovation for sustainability: The impact of R\&D spending on CO2 emissions. J. Clean. Prod. 2018, 172, 3459-3467.

67. Ramanathan, R.; He, Q.; Black, A.; Ghobadian, A.; Gallear, D. Environmental regulations, innovation and firm performance: A revisit of the Porter hypothesis. J. Clean. Prod. 2017, 155, 79-92. [CrossRef]

68. De Medeiros, J.F.; Ribeiro, J.L.D. Environmentally sustainable innovation: Expected attributes in the purchase of green products. J. Clean. Prod. 2017, 142, 240-248. [CrossRef]

69. Blok, V.; Long, T.B.; Gaziulusoy, A.I.; Ciliz, N.; Lozano, R.; Huisingh, D.; Csutora, M.; Boks, C. From best practices to bridges for a more sustainable future: Advances and challenges in the transition to global sustainable production and consumption. J. Clean. Prod. 2015, 108, 19-30. [CrossRef]

70. Shin, J.; Kim, C.; Yang, H. The Effect of Sustainability as Innovation Objectives on Innovation Efficiency. Sustainability 2018, 10, 1966. [CrossRef]

71. Mirata, M.; Emtairah, T. Industrial symbiosis networks and the contribution to environmental innovation. J. Clean. Prod. 2005, 13, 993-1002. [CrossRef]

72. Li, K.; Song, M. Green Development Performance in China: A Metafrontier Non-Radial Approach. Sustainability 2016, 8, 219. [CrossRef]

73. Liu, X.; Guo, P.; Guo, S. Assessing the eco-efficiency of a circular economy system in China's coal mining areas: Emergy and data envelopment analysis. J. Clean. Prod. 2019, 206, 1101-1109. [CrossRef]

74. Yin, J.; Gong, L.; Wang, S. Large-scale assessment of global green innovation research trends from 1981 to 2016: A bibliometric study. J. Clean. Prod. 2018, 197, 827-841. [CrossRef]

75. Fu, J.; Xiao, G.; Guo, L.; Wu, C. Measuring the Dynamic Efficiency of Regional Industrial Green Transformation in China. Sustainability 2018, 10, 628.

76. Li, Z.; Tang, D.; Han, M.; Bethel, B. Comprehensive Evaluation of Regional Sustainable Development Based on Data Envelopment Analysis. Sustainability 2018, 10, 3897. [CrossRef]

77. Chen, S.; Huang, Q.; Liu, Z.; Meng, S.; Yin, D.; Zhu, L.; He, C. Assessing the Regional Sustainability of the Beijing-Tianjin-Hebei Urban Agglomeration from 2000 to 2015 Using the Human Sustainable Development Index. Sustainability 2019, 11, 3160. [CrossRef]

78. Shen, H.; Teng, F.; Song, J. Evaluation of Spatial Balance of China's Regional Development. Sustainability 2018, 10, 3314. [CrossRef]

79. Chen, L.; Zhang, X.; He, F.; Yuan, R. Regional green development level and its spatial relationship under the constraints of haze in China. J. Clean. Prod. 2019, 210, 376-387. [CrossRef] 
80. Zheng, D.; Shi, M. Multiple environmental policies and pollution haven hypothesis: Evidence from China's polluting industries. J. Clean. Prod. 2017, 141, 295-304. [CrossRef]

81. Zheng, S.; Yi, H.; Li, H. The impacts of provincial energy and environmental policies on air pollution control in China. Renew. Sustain. Energy Rev. 2015, 49, 386-394. [CrossRef]

82. Zheng, W.; Walsh, P.P. Economic growth, urbanization and energy consumption-A provincial level analysis of China. Energy Econ. 2019, 80, 153-162. [CrossRef]

83. Zhao, J.; Tang, J. Industrial structure change and economic growth: A China-Russia comparison. China Econ. Rev. 2018, 47, 219-233. [CrossRef]

84. Higgins, P.; Zha, T.; Zhong, W. Forecasting China's economic growth and inflation. China Econ. Rev. 2016, 41, 46-61. [CrossRef]

85. Wang, Q.; Jiang, R. Is China's economic growth decoupled from carbon emissions? J. Clean. Prod. 2019, 225, 1194-1208. [CrossRef]

86. Lee, S.; Oh, D.-W. Economic growth and the environment in China: Empirical evidence using prefecture level data. China Econ. Rev. 2015, 36, 73-85. [CrossRef]

87. Lu, Z.-N.; Chen, H.; Hao, Y.; Wang, J.; Song, X.; Mok, T.M. The dynamic relationship between environmental pollution, economic development and public health: Evidence from China. J. Clean. Prod. 2017, 166, 134-147. [CrossRef]

88. Liang, W.; Yang, M. Urbanization, economic growth and environmental pollution: Evidence from China. Sustain. Comput. Inform. Syst. 2019, 21,1-9. [CrossRef]

89. Wang, K.; Wei, Y.-M.; Zhang, X. Energy and emissions efficiency patterns of Chinese regions: A multi-directional efficiency analysis. Appl. Energy 2013, 104, 105-116. [CrossRef]

90. Chen, A.; Groenewold, N. China's 'New Normal': Is the growth slowdown demand- or supply-driven? China Econ. Rev. 2018. [CrossRef]

91. Li, K.; Lin, B. Economic growth model, structural transformation, and green productivity in China. Appl. Energy 2017, 187, 489-500. [CrossRef]

92. Qu, Y.; Yu, Y.; Appolloni, A.; Li, M.; Liu, Y. Measuring Green Growth Efficiency for Chinese Manufacturing Industries. Sustainability 2017, 9, 637. [CrossRef]

93. Bi, G.; Wang, P.; Yang, F.; Liang, L. Energy and Environmental Efficiency of China's Transportation Sector: A Multidirectional Analysis Approach. Math. Probl. Eng. 2014, 2014, 539596. [CrossRef]

94. Broekel, T. Do Cooperative Research and Development (R\&D) Subsidies Stimulate Regional Innovation Efficiency? Evidence from Germany. Reg. Stud. 2013, 49, 1087-1110.

95. Pakes, A.; Griliches, Z. Patents and R\&D at the firm level: A first report. Econ. Lett. 1980, 5, 377-381.

96. Hall, B.H.; Griliches, Z.; Hausman, J.A. Patents and R and D: Is There a Lag? Int. Econ. Rev. 1986, $27,265$. [CrossRef]

97. Mansfield, E. Industrial innovation in Japan and the United States. Science 1988, 241, 1769-1774. [CrossRef]

98. Acs, Z.J.; Anselin, L.; Varga, A. Patents and innovation counts as measures of regional production of new knowledge. Res. Policy 2002, 31, 1069-1085. [CrossRef]

99. Zabala-Iturriagagoitia, J.M.; Voigt, P.; Gutiérrez-Gracia, A.; Jiménez-Sáez, F. Regional Innovation Systems: How to Assess Performance. Reg. Stud. 2007, 41, 661-672. [CrossRef]

100. Carayannis, E.G.; Grigoroudis, E.; Goletsis, Y. A multilevel and multistage efficiency evaluation of innovation systems: A multiobjective DEA approach. Expert Syst. Appl. 2016, 62, 63-80. [CrossRef]

101. Chen, K.; Kou, M.; Fu, X. Evaluation of multi-period regional R\&D efficiency: An application of dynamic DEA to China's regional R\&D systems. Omega 2018, 74, 103-114.

102. Sueyoshi, T.; Yuan, Y.; Goto, M. A literature study for DEA applied to energy and environment. Energy Econ. 2017, 62, 104-124. [CrossRef]

103. Emrouznejad, A.; Yang, G.-1. A survey and analysis of the first 40 years of scholarly literature in DEA: 1978-2016. Socio-Econ. Plan. Sci. 2018, 61, 4-8. [CrossRef]

104. Mardani, A.; Zavadskas, E.K.; Streimikiene, D.; Jusoh, A.; Khoshnoudi, M. A comprehensive review of data envelopment analysis (DEA) approach in energy efficiency. Renew. Sustain. Energy Rev. 2017, 70, 1298-1322. [CrossRef]

105. Charnes, A.; Cooper, W.W.; Rhodes, E. Measuring the efficiency of decision making units. Eur. J. Oper. Res. 1978, 2, 429-444. [CrossRef] 
106. Banker, R.D.; Charnes, A.; Cooper, W.W. Some Models for Estimating Technical and Scale Inefficiencies in Data Envelopment Analysis. Manag. Sci. 1984, 30, 1078-1092. [CrossRef]

107. Tone, K. A slacks-based measure of efficiency in data envelopment analysis. Eur. J. Oper. Res. 2001, 130, 498-509. [CrossRef]

108. Tone, K.; Sahoo, B.K. Degree of scale economies and congestion: A unified DEA approach. Eur. J. Oper. Res. 2004, 158, 755-772. [CrossRef]

109. Bai, Y.; Hua, C.; Jiao, J.; Yang, M.; Li, F. Green efficiency and environmental subsidy: Evidence from thermal power firms in China. J. Clean. Prod. 2018, 188, 49-61. [CrossRef]

110. Li, B.; Wu, S. Effects of local and civil environmental regulation on green total factor productivity in China: A spatial Durbin econometric analysis. J. Clean. Prod. 2017, 153, 342-353. [CrossRef]

111. Hu, J.-L.; Wang, S.-C. Total-factor energy efficiency of regions in China. Energy Policy 2006, 34, $3206-3217$. [CrossRef]

112. Chen, K.; Guan, J. Mapping the innovation production process from accumulative advantage to economic outcomes: A path modeling approach. Technovation 2011, 31, 336-346. [CrossRef]

113. Evangelista, R.; Iammarino, S.; Mastrostefano, V.; Silvani, A. Measuring the regional dimension of innovation. Lessons from the Italian Innovation Survey. Technovation 2001, 21, 733-745. [CrossRef]

114. Yang, T.; Chen, W.; Zhou, K.; Ren, M. Regional energy efficiency evaluation in China: A super efficiency slack-based measure model with undesirable outputs. J. Clean. Prod. 2018, 198, 859-866. [CrossRef]

115. Wang, K.; Wei, Y.-M.; Zhang, X. A comparative analysis of China's regional energy and emission performance: Which is the better way to deal with undesirable outputs? Energy Policy 2012, 46, 574-584. [CrossRef]

116. Jiang, J.; Ye, B.; Xie, D.; Li, J.; Miao, L.; Yang, P. Sector decomposition of China's national economic carbon emissions and its policy implication for national ETS development. Renew. Sustain. Energy Rev. 2017, 75, 855-867. [CrossRef]

117. Zhang, Y.-J.; Peng, Y.-L.; Ma, C.-Q.; Shen, B. Can environmental innovation facilitate carbon emissions reduction? Evidence from China. Energy Policy 2017, 100, 18-28. [CrossRef]

118. Feng, Z.; Tang, W.; Niu, Z.; Wu, Q. Bi-level allocation of carbon emission permits based on clustering analysis and weighted voting: A case study in China. Appl. Energy 2018, 228, 1122-1135. [CrossRef]

119. Li, H.; Mu, H.; Zhang, M.; Gui, S. Analysis of regional difference on impact factors of China's energy-Related $\mathrm{CO}_{2}$ emissions. Energy 2012, 39, 319-326. [CrossRef]

120. Hu, X.; Chen, L.; Lei, H. China's Low Carbon Development Pathways by 2050, Scenario Analysis of Energy Demand and Carbon Emissions; Science Press: Beijing, China, 2009.

121. Guan, J.; Chen, K. Modeling macro-R\&D production frontier performance: An application to Chinese province-level R\&D. Scientometrics 2009, 82, 165-173.

122. Guan, J.; Chen, K. Measuring the innovation production process: A cross-region empirical study of China's high-tech innovations. Technovation 2010, 30, 348-358. [CrossRef]

123. Wang, N.; Hagedoorn, J. The lag structure of the relationship between patenting and internal R\&D revisited. Res. Policy 2014, 43, 1275-1285.

124. Wang, E.C.; Huang, W. Relative efficiency of R\&D activities: A cross-country study accounting for environmental factors in the DEA approach. Res. Policy 2007, 36, 260-273.

125. Hollanders, H.; Celikel-Esser, F. Measuring Innovation Efficiency; INNO Metrics 2007 Report; European Commission, DG Enterprise: Brussels, Belgium, 2007.

126. Griliches, Z. Patents Statistics as Economic Indicators: A survey. J. Econ. Lit. 1998, 18, 1707.

127. Li, H.; Wei, Y.-M.; Mi, Z. China's carbon flow: 2008-2012. Energy Policy 2015, 80, 45-53. [CrossRef]

128. Chunmei, W.; Zhaolan, L. Environmental Policies in China over the Past 10 Years: Progress, Problems and Prospects. Proced. Environ. Sci. 2010, 2, 1701-1712. [CrossRef]

129. Han, R.; Tang, B.-J.; Fan, J.-L.; Liu, L.-C.; Wei, Y.-M. Integrated weighting approach to carbon emission quotas: An application case of Beijing-Tianjin-Hebei region. J. Clean. Prod. 2016, 131, 448-459. [CrossRef]

130. Lin, S.; Sun, J.; Marinova, D.; Zhao, D. Evaluation of the green technology innovation efficiency of China's manufacturing industries: DEA window analysis with ideal window width. Technol. Anal. Strateg. Chang. 2018, 30, 1166-1181. [CrossRef]

131. Wang, Q.; Hang, Y.; Sun, L.; Zhao, Z. Two-stage innovation efficiency of new energy enterprises in China: A non-radial DEA approach. Technol. Forecast. Soc. 2016, 112, 254-261. [CrossRef] 
132. Berchicci, L. Towards an open R\&D system: Internal R\&D investment, external knowledge acquisition and innovative performance. Res. Policy 2013, 42, 117-127.

133. Czarnitzki, D.; Toole, A.A. Patent Protection, Market Uncertainty, and R\&D Investment. Rev. Econ. Stat. 2011, 93, 147-159. 